\title{
Histological study on the effect of adipose tissue-derived mesenchymal stem cells on the testis of chemically induced castration model by calcium chloride in adult albino rats
}

\author{
Original \\ Article \\ Suzi Sobhy Atalla, Hanan A. Saleh, Sara Abdel Gawad, and Hend Mohamed \\ Department of Histology \& Cell Biology, Faculty of Medicine, Ain Shams University, Cairo, \\ Egypt
}

\begin{abstract}
Background: Male infertility is considered a major cause of couple infertility as it represents $25-50 \%$ of infertility cases. In addition, non-obstructive azoospermia (NOA) represents $10 \%$ of all infertile men. There is no definite curable treatment for such cases.

Aim of the work: To evaluate the therapeutic role of adipose tissue-derived mesenchymal stem cells (ADMSCs) in the treatment of $\mathrm{CaCl}_{2}$ castration model in adult male albino rats.

Materials and Methods: Forty five adult male albino rats were divided into 4 groups. Group I (control group), Group II $\left(\mathrm{CaCl}_{2}\right.$ group), Group III (stem cell treated group), Group IV (recovery group). Testes were dissected out and processed for light and electron microscopic examination. Sperm count and testosterone hormonal assay were done. Morphometric and statistical analysis were performed.

Results: Histological examination of the testes of both groups II and IV revealed severe degeneration of seminiferous tubules with sloughing of spermatogenic cells. Inflammatory cells and multinucleated giant cells were obvious in group II while macrophages were detected more clearly in group IV. Collagen fibers deposition was detected in the interstitium and inside seminiferous tubules in group IV. Sperm count and serum testosterone levels were significantly decreased in both groups comparable with that of the control group. Intratesticular injection of ADMSCs in group III resulted in improvement of the histological architecture of testicular tissue which was documented by non significant changes in sperm count and serum testosterone when compared to that of the control group.
\end{abstract}

Conclusions: Adipose tissue-derived mesenchymal stem cells (ADMSCs) could be considered an effective treatment in NOA.

Key Words: Adipose-tissue derived mesenchymal stem cells, $\mathrm{CaCl}_{2}$, Calcium Chloride, histology, NOA, non obstructive azoospermia, rats

Revised: 29 August 2017, Accepted: 29 September 2017

Corresponding Author: Sara Elsebay, M.D, Department of Histology and Cell Biology, Faculty of Medicine, Ain Shams University, Cairo, Egypt, Tel.: 0201067800614, E-mail: saraelsebay@yahoo.com

ISSN: $1110-0559$, Vol. 40, No. 4

\section{INTRODUCTION}

The prevalence of infertility has steadily increased over the past decade reaching $10 \%-15 \%$ of the sexually active population ${ }^{[1]}$. According to different surveys, male factor infertility appeared to be the culprit in $25 \%-50 \%$ of infertility cases ${ }^{[2]}$. One of the principal causes of male infertility is oligospermia or even azoospermia which might be due to non obstructive causes (pre-testicular and testicular) and obstructive causes (post testicular) ${ }^{[3]}$.

Various conditions could cause NOA such as genetic or congenital abnormalities, infections, exposure to toxins, medications as systemic chemotherapy or radiotherapy to the testis, and idiopathic causes ${ }^{[4]}$.

Current medical therapy; including hormone or surgical methods; showed little benefit to patients with $\mathrm{NOA}^{[5]}$. The use of gonadotropins had been reported to increase the sperm count in the ejaculate and to increase the success rates of in vitro fertilization in men with $\mathrm{NOA}^{[3]}$. Another method for treatment of cases with NOA could be the use of aromatase inhibitors; aromatase is responsible for converting testosterone and other androgens to estradiol in men $^{[3]}$; as low-doses of oral aromatase inhibitors would block this conversion ${ }^{[6]}$.

Finally, all the above mentioned methods of treatments of NOA cases could not be considered as curable treatment. So, recently, the researches became directed towards the potential use of stem cells such as mesenchymal stem cells (MSCs) in treating such cases ${ }^{[7]}$. This relies on the ease of their isolation from several human tissues, such as bone marrow, adipose tissue, and placenta ${ }^{[8]}$. In addition, MSCs are characterized by their extensive capacity for in vitro expansion and have multipotential differentiation capacity ${ }^{[9]}$.

Recently, the scientists start to search for an alternative for bone marrow MSCs as the isolation of MSCs from 
the bone marrow is presented with pain, morbidity, and low cell number upon harvest ${ }^{[10]}$. Adipose tissue derived mesenchymal stem cells (ADMSCs) are derived from the mesenchyme which contains supportive stroma that is easily isolated, therefore it is thought that adipose tissue might represent a source of stem cells that could have farreaching effects on several fields ${ }^{[10]}$.

Investigators have suggested a number of mechanisms through which ADMSCs can repair and regenerate tissues. First, ADMSCs might secrete cytokines and growth factors that stimulate recovery ${ }^{[11]}$, also ADMSCs could suppress immune reaction ${ }^{[12,13]}$, and modulate the "stem cell niche"[11]

Given the aforementioned data, the aim of the present study was to induce a model of male infertility (NOA) using $\mathrm{CaCl}_{2}$ injection with detection of the subsequent structural changes occurring in the testes and also to evaluate the therapeutic role of ADMSCs in the treatment of such model.

\section{PATIENTS AND METHODS}

\section{Animals:}

Forty five adult male albino rats weighing 200-250 gm were included in this study. The animals were purchased from and raised in the Medical Research Center, Ain Shams University and were treated in accordance with the valid International Guidelines for animal experimentation.

\section{Experimental Design:}

Animals were randomly divided into four groups. Rats in group I (control group) were equally subdivided into subgroups Ia, Ib, Ic; 5 rats each. Rats in subgroups Ia and $\mathrm{Ib}$ were injected with a single intra-testicular dose of 0.1 $\mathrm{ml}$ saline/100 gm body weight and were sacrificed after 1 and 9 weeks respectively. Subgroup Ic served as donors for stem cells obtained from their adipose tissue. Group II rats (Calcium Chloride group) $(\mathrm{n}=10)$ were subjected to a single intra-testicular injection of $\mathrm{CaCl}_{2}$ in a dose of $2.5 \mathrm{mg} /$ testis/100gm body weight dissolved in $0.1 \mathrm{ml}$ normal saline and were sacrificed after one week. Group III rats (ADMSCs treated group) $(\mathrm{n}=10)$ were treated by $\mathrm{CaCl}_{2}$ as in group II and after one week from $\mathrm{CaCl}_{2}$ injection, $100 \mu \mathrm{l}$ of ADMSCs mixture $\left(10^{6}\right.$ cells $)$ in $0.1 \mathrm{ml}$ normal saline/testis was injected intra-testicular and animals were sacrificed eight weeks after stem cells injection. Group IV (Recovery group) ( $\mathrm{n}=10)$ were treated by $\mathrm{CaCl}_{2}$ in the same manner as in group II and were sacrificed after nine weeks to be compared with group III.

All groups were given $1 \mathrm{ml}$ oral paracetamol syrup (Epico Medical Company) for three days to prevent neurogenic shock and fever after the injection.

Mating between two female rats with one male rat was done for ten days to the four groups. After two weeks the females' abdomen were examined for the expected pregnancy ${ }^{[7]}$.

\section{Calcium chloride intra-testicular injection:}

Under light ether anesthesia, $\mathrm{CaCl}_{2}$ were given as a single bilateral intra-testicular injection. The needle was directed from the codo-ventral aspect of each testis approximately $0.5 \mathrm{~cm}$ from the epididymal tail; at the midline; towards the dorso-cranial aspect. The solution was carefully deposited along the entire route by linear infiltration while withdrawing the needle from proximal to distal end. Necessary care was taken to prevent the seepage of the solution from the injection site ${ }^{[14,15]}$.

\section{Preparation and isolation of ADMSCs:}

Peri-peritoneal adipose tissue measuring about 1-2 $\mathrm{cm} 3$ (omentum fat pad) was removed from the rats, minced, and incubated in $1 \mathrm{mg} / 1 \mathrm{ml}$ of $0.075 \%$ collagenase II solution (purchased from Sigma Company) in the incubator at $37^{\circ} \mathrm{C}$ for one hour. The suspension was centrifuged to form a cell pellet which suspended in Dulbecco's modified Eagle's medium (DMEM) supplemented with 10\% fetal bovine serum (FBS) and 1\% penicillin-streptomycin (purchased from Lonza company, Swiss) then seeded in culture dishes and incubated at $37^{\circ} \mathrm{c}$ in $5 \%$ humidified $\mathrm{CO}_{2}$ for 2 3 days or upon formation of large colonies. When large colonies were developed (80 90\% confluence), cultures were washed twice with PBS and the cells were detached using $0.25 \%$ trypsin (purchased from Lonza Company, Swiss) in $1 \mathrm{mM}$ EDTA for $5 \mathrm{~min}$ at $37^{\circ} \mathrm{C}$. The suspension was then centrifuged and viable and non-viable cells were counted using a hemocytometer followed by subculturing the viable cells at $4 \times 10^{3}$ cells $/ \mathrm{cm}^{2}$ which were used for experiment after the third passage $\mathrm{e}^{[7]}$.

ADMSCs in culture were characterized by their adhesiveness and fusiform shape (Fig. 1A and 1B).

\section{Characterization of ADMSCs by flow cytometry}

analysis:

After the third passage, the undifferentiated ADMSCs were subjected to flow cytometer analysis to detect the following antigens: CD90 and CD45 by using monoclonal antibodies specific for each antigen. Adherent cells were adjusted to $1 \times 10^{5}$ cells $/ \mathrm{ml}$ and were trypsinized in $0.25 \%$ trypsin/ EDTA, fixed for 30 min in ice-cold $2 \%$ formaldehyde then the fixed cells washed in flow cytometry buffer and incubated for $30 \mathrm{~min}$ in flow cytometry buffer containing fluorescein isothiocyanate-conjugated monoclonal antibodies: CD90 PE and CD45 PeCy7 IgG1 (Beckman coulter, USA) at $4^{\circ} \mathrm{C}$ in the dark. Then $2 \mathrm{ml}$ of PBS containing 2\% FBS solution was added to each tube of monoclonal treated cells then the cells were centrifuged and re-suspended in 500 $\mu \mathrm{l}$ PBS containing $2 \%$ FBS 
solution. Cell analysis was performed using CYTOMICS FC 500 Flow Cytometer (Beckman coulter, FL, USA) and analyzed using CXP Software version $2.2^{[10]}$.

Flow cytometry analysis of ADMSCs revealed positive expression of CD90 (Diagram A1) and negative expression of CD45 (Diagram A2).

\section{Fluorescence labeling for in vivo tracking of}

\section{ADMSCS:}

Adipose tissue derived mesenchymal stem cells were labeled using PKH26 red fluorescence cell linker kit (Sigma Aldrich, USA) according to the manufacturer's protocol. In brief, subconfluent ADMSCs after the third passage were detached and washed three times with serumfree medium and resuspended in $1 \mathrm{~mL}$ of dilution buffer. The cells' suspension was mixed with an equal volume of the labeling solution containing $4 \times 10^{-6} \mathrm{M}$ PKH26 in the dilution buffer and incubated for $5 \mathrm{~min}$. To stop the reaction, $2 \mathrm{ml}$ of FBS was added. Cells were supplemented with $4 \mathrm{ml}$ of complete medium and washed three times. Then Cells were resuspended at $1 \times 10^{6}$ cells in complete medium and used within $30 \mathrm{~min}$. For assessment of vitality and preservation of differentiation capacity of PKH26-labeled ADMSCs, cells were reseeded onto plates and then underwent differentiation testing upo $\mathrm{n}$ reaching confluence ${ }^{[16]}$.

Fluorescent microscope examination of the testes specimens of the rats that were treated with the labeled ADMSCs (group III) was done to insure their incorporation into the testicular tissue (Fig. 1C).

\section{ADMSCs intra-testicular injection:}

The cell suspension was injected into the lumen of the seminiferous tubules of the recipient rat testis (Group III) by the same way described before of $\mathrm{CaCl}_{2}$ intra-testicular injection.

\section{Histological study:}

For light microscopic examination; testis samples were fixed in $10 \%$ buffered formalin, dehydrated, cleared, and embedded in paraffin. Serial $5 \mu \mathrm{m}$ sections of the testis were stained with hematoxylin and eosin (H\&E) and Masson trichrome stain.

For transmission electron microscope (TEM) examination, small testis specimens $\left(1 \mathrm{~mm}^{3}\right)$ were fixed in $2.5 \%$ gluteraldhyde solution, followed by $1 \%$ osmium tetroxide, dehydrated, and embedded in epoxy resin. Ultrathin sections 50-60 nm were collected on copper grids and stained with uranyl acetate and lead citrate. Finally, the sections were examined and photographed under Jeol TEM 1200 Ex in Faculty of Science, Ain Shams University.

\section{Sperm count smears sections preparation:}

The rats of each group were sacrificed and their epididymis was removed. Two sperm suspensions were prepared from the cauda of each testis by mincing the cauda in physiological saline. Smears were prepared on grease-free slides after staining with $1 \%$ eosin for $45 \mathrm{~min}$. The slides were air dried and examined using the image analyzer ${ }^{[17]}$.

\section{Hormonal Assay:}

The total plasma testosterone level $(\mathrm{ng} / \mathrm{ml})$ was measured for the different groups in Medical Research Center, Faculty of Medicine, Ain Shams University.

\section{Morphometric measurements:}

The surface area of seminiferous tubules, height of the spermatogenic epithelium, and sperm count of Eosin stained sections were measured in randomly chosen five fields/ section in five sections for every rat in each group at magnification 400 . The different parameters were measured using the image analyzer Leica Q win V.3 program and the computer was connected to a Leica DM2500 microscope (Wetzlar, Germany).

\section{Statistical analysis:}

The measured parameters as well as the mean total testosterone level in the different groups were compared with each other using the statistical package for the social sciences (SPSS program version17) computer program analysis for variance (ANOVA)-one way analysis and post-Hoc least significant difference (LSD). Differences were considered significant when the $p$ value was $\leq 0.05$. Summary of the data was expressed as mean \pm standard deviation (SD).

\section{RESULTS}

\section{Gross examination of the testes:}

By gross examination, the testes of the rats in the control group appeared pink in color with smooth surface. The capsule was transparent and glistening. The average weight and length of the testis and epididymis were 2.02 gm and $1.81 \mathrm{~cm}$ respectively (Fig.2A). In group II, the testes appeared atrophied and the capsule was opaque with hemorrhagic spots on its surface. The mean weight and length of the testis and epididymis were $0.93 \mathrm{gm}$ and 0.71 $\mathrm{cm}$ respectively (Fig. 2B). Nevertheless, the testes in group III appeared similar to the control group and the average weight and length were $1.9 \mathrm{gm}$ and $1.84 \mathrm{~cm}$ respectively (Fig. 2C). In group IV, the testes were markedly shrunken with hemorrhagic capsule. The mean weight and length of the testis and epididymis were $0.69 \mathrm{gm}$ and $0.52 \mathrm{~cm}$ respectively (Fig. 2D). 
Moreover, male fertility was confirmed by successful mating and viable offspring production after 22 days of gestation in the control group. The rats in both groups II and IV revealed infertility with no offspring production. However, rats of group III showed restoration of male fertility with capability of giving offspring's.

\section{Light microscopic examination:}

Histological examination of H\&E stained sections of the testes in both subgroup Ia, Ib (control group) revealed the same histological structure as the testes appeared surrounded by a regular connective tissue capsule; the tunica albuginea. The seminiferous tubules appeared closely packed and lined by spermatogenic epithelium which formed of; spermatogonia, primary spermatocytes, spermatids, and sperms. Sertoli cells with large pale nuclei were seen between the spermatogenic cells and resting on the basement membrane. The seminiferous tubules were ensheathed by a well-defined basement membrane and surrounded by flattened myoid cells with flattened nuclei. The tubules separated from each other by loose interstitial connective tissue containing the Leydig cells which appeared with vesicular nuclei and cytoplasmic lipid droplets (Figures. 3A, 4A). In group II $\left(\mathrm{CaCl}_{2}\right.$ group for one week), there was distortion of the testicular structure as many tubules were completely devoid of spermatogenic epithelium and few contained remnants of the epithelial cells while other tubules contained only dark necrotic hyalinosed material with congested blood vessels in the interstitium (Fig. 3B). Spermatogenic epithelium appeared with dark exfoliated pyknotic nuclei with preservation of the Sertoli cells only. Multinucleated large giant cells could be detected in tubules' lumina with absence of sperms (Fig. 4B). Meanwhile, sections of testes of group III showed nearly the normal histological profile (Figs. 3C, $4 C)$. In group IV, there was severe distortion of most of the seminiferous tubules with loss of their normal histological architecture as the tubules were shrunken, atrophied, and completely devoid of spermatogenic epithelium which replaced by structureless hyalanosed necrotic material. Heavy mononuclear cellular infiltrations were seen in the interstitial tissue (Figs. 3D, 4D).

Examination of sperm smears' sections in the control group revealed normal sperm morphology as the sperms appeared with hook shaped head (Fig. 5A). However, group II showed morphological abnormalities in the form of pyriform head and coiled tail (Fig. 5B). Sperm morphology in group III was comparative to that of the control group (Fig. 5C). In group IV, there was sever morphological abnormalities as the sperms appeared only as fragments with detached heads (Fig. 5D).

Using Masson trichrome stain, the tunica albuginea in the control group was formed of dense connective tissue with minimal collagen fibers content in between the seminiferous tubules (Fig. 6A). Group II showed extensive necrotic tissue deposition inside tubules' lumina (Fig. 6B).
However, tunica albuginea of group III exhibited minimal collagen fibers in the interstitium (Fig. 6C). In group IV, tunica albuginea appeared thickened with splitting of its layers and all seminiferous tubules were filled with necrotic tissues. Extensive collagen fibers deposition was detected the interstitium (Fig. 6D).

\section{Electron microscopic examination:}

Ultra-thin sections of testis specimens of the control group showed that the seminiferous tubules were surrounded by regular trilaminar basement membrane and were lined by spermatogenic epithelium; spermtogonia which found resting on the basement membrane with heterochromatic nuclei, primary spermatocytes located in many rows with large central rounded nuclei and their cytoplasm exhibited clusters of mitochondria with clear matrix, and early spermatids which appeared as small spherical cells covered by acrosomal caps. Sertoli cells were tall pyramidal cells resting on the basement membrane with folded nuclei (Fig. 7A). The interstitial Leydig cells showed large eccentric nuclei with peripherally situated chromatin (Fig. 8A). However, group II revealed predominance of the Sertoli cells with loss of other spermatogenic cells in the majority of the seminiferous tubules. Most of the spermatogenic epithelium was severely distorted with excessive cytoplasmic vaculations and some of them revealed fragmented nuclei. The basement membrane appeared highly corrugated, thickened, and trapping cellular debris between its layers. Sertoli cells revealed moderately electron dense nuclei with prominent nucleoli (Fig. 7B). Some of Leydig cells appeared with shrunken infolded nuclei while others showed electron dense nuclei with thickened nuclear membrane and few cytoplasmic organelles (Fig.8B). Ultrastructural examination of the testes of group III revealed features that were nearly similar to those of the control group. Spermtogonia were clearly observed resting on regular trilaminar basement membrane. Primary spermatocytes were seen with their large rounded nuclei and spermatid appeared with rounded euchromatic nucleus. Sertoli cells showed large irregular nuclei with prominent nucleoli and abundant mitochondria (Fig. 7C). The Leydig cells appeared oval with large eccentric nuclei and peripherally situated chromatin with some cells revealed folded nuclei. Their cytoplasm had numerous mitochondria and fat droplets (Fig. 8C). In group IV, there was complete cellular loss, only little cellular debris with cytoplasmic vacuolations could be seen. The basement membrane was severely irregular and highly corrugated with apparent collagen fibers deposition under the basement membrane (Fig. 7D). Additionally, Leydig cells were shrunken with irregular folded fragmented nuclei and the cytoplasm appeared devoid of organelles (Fig. 8D).

\section{Morphometric \& statistical results:}

In group II and group IV, there was a significant decrease $(P<0.05)$ in the surface area of seminiferous 
tubules and the height of the spermatogenic epithelium when compared with the control group. On the other hand, group III showed a significant increase $(P<0.05)$ in the previous parameters compared with both groups II\&IV whereas a non-significant change was documented when compared with the control group (Table 1).

The mean number of sperm count showed a significant decrease $(P<0.05)$ in both groups II\&IV when compared with the control group. However, intra-testicular injection of ADMSCs in group III significantly $(P<0.05)$ restored the normal sperm count as compared with both groups III and IV (Table 1).

Concerning plasma testosterone level, it was significantly $(P<0.05)$ decreased in groups II\&IV when compared with control group. However, in group III testosterone level was significantly increased $(P<0.05)$ comparable with groups II\&IV with non-significant change when compared with group I (Table 1).

Table (1): Showing the mean surface area of seminiferous tubules, spermatogenic epithelial thickness, epididymal sperm count, and total serum testosterone level

\begin{tabular}{|c|c|c|c|c|}
\hline & Group I & Group II & Group III & Group IV \\
\hline $\begin{array}{l}\text { Surface area of } \\
\text { the seminiferous } \\
\text { tubules }\left(\mu \mathrm{m}^{2}\right)\end{array}$ & $\begin{array}{c}118321.66 \pm \\
107125.5(\square \mathrm{O})\end{array}$ & $\begin{array}{c}19787.18 \pm 6468.916 \\
(* \mathbf{\Delta})\end{array}$ & $\begin{array}{c}81325.07 \pm 43854.62 \\
(\square \mathrm{O})\end{array}$ & $\begin{array}{c}33948.56 \pm 17648.15 \\
(* \boldsymbol{\Lambda})\end{array}$ \\
\hline $\begin{array}{l}\text { Spermatogenic epithelial } \\
\text { thickness }(\mu \mathrm{m})\end{array}$ & $\begin{array}{c}77.29 \pm 18.651 \\
(\square \mathrm{O})\end{array}$ & $20.01 \pm 6.064(* \mathbf{\Lambda})$ & $\begin{array}{c}62.92 \pm 10.771 \\
(\square \mathrm{O})\end{array}$ & $\begin{array}{l}8.21 \pm 5.248 \\
\quad(* \mathbf{\Delta})\end{array}$ \\
\hline Epididymal sperm count & $\begin{array}{l}40.68 \pm 0 \\
\quad(\square \mathrm{O})\end{array}$ & $\begin{array}{l}2.04 \pm 0.589 \\
\quad(* \mathbf{\Lambda})\end{array}$ & $\begin{array}{l}38.68 \pm 0 \\
\quad(\square \mathrm{O})\end{array}$ & $\begin{array}{l}0.52 \pm 0.872 \\
\quad(* \boldsymbol{\Delta})\end{array}$ \\
\hline $\begin{array}{l}\text { Total serum Testosterone } \\
\text { level }(\mathrm{ng} / \mathrm{ml})\end{array}$ & $\begin{array}{l}4.5 \pm 0.56 \\
\quad(\square \mathrm{O})\end{array}$ & $\begin{array}{l}0.26 \pm 0.114 \\
\quad(* \boldsymbol{\Delta})\end{array}$ & $4.53 \pm 0.564(\square \mathrm{O})$ & $\begin{array}{l}0.03 \pm 0.025 \\
\quad(* \boldsymbol{\Delta})\end{array}$ \\
\hline
\end{tabular}

* Significant difference from group I.

$\square$ Significant difference from group II.

$\Delta$ Significant difference from group III.

O Significant difference from group IV.



Fig. 1: (A) Culture on day four, showing adherent spindle shaped cells with multiple interlacing cytoplasmic processes $(\uparrow)$. They have granular cytoplasm and vesicular nuclei. Few rounded cells are also visualized ( $\uparrow$ ) (Inverted microscope x200). (B) Culture on day eight, showing confluent dense homogenous fibroblast like cells giving whorly appearance (Inverted microscope x200). (C) Show PKH26 labeled ADMSCs are seen scattered in the testis tissue of ADMCs treated group (fluorescent microscope, group III). 



Fig. 2: (A) Show the testis appears pink in color with smooth surface. The capsule is transparent and glistening (Gross examination, Subgroup Ia). (B) Show atrophy of the testis with opaque hemorrhagic capsule (Gross examination, Group II). (C) Show apparently normal testis (Gross examination, Group III). (D) Show markedly shrunken testis with thick hemorrhagic capsule (Gross examination, Group IV).
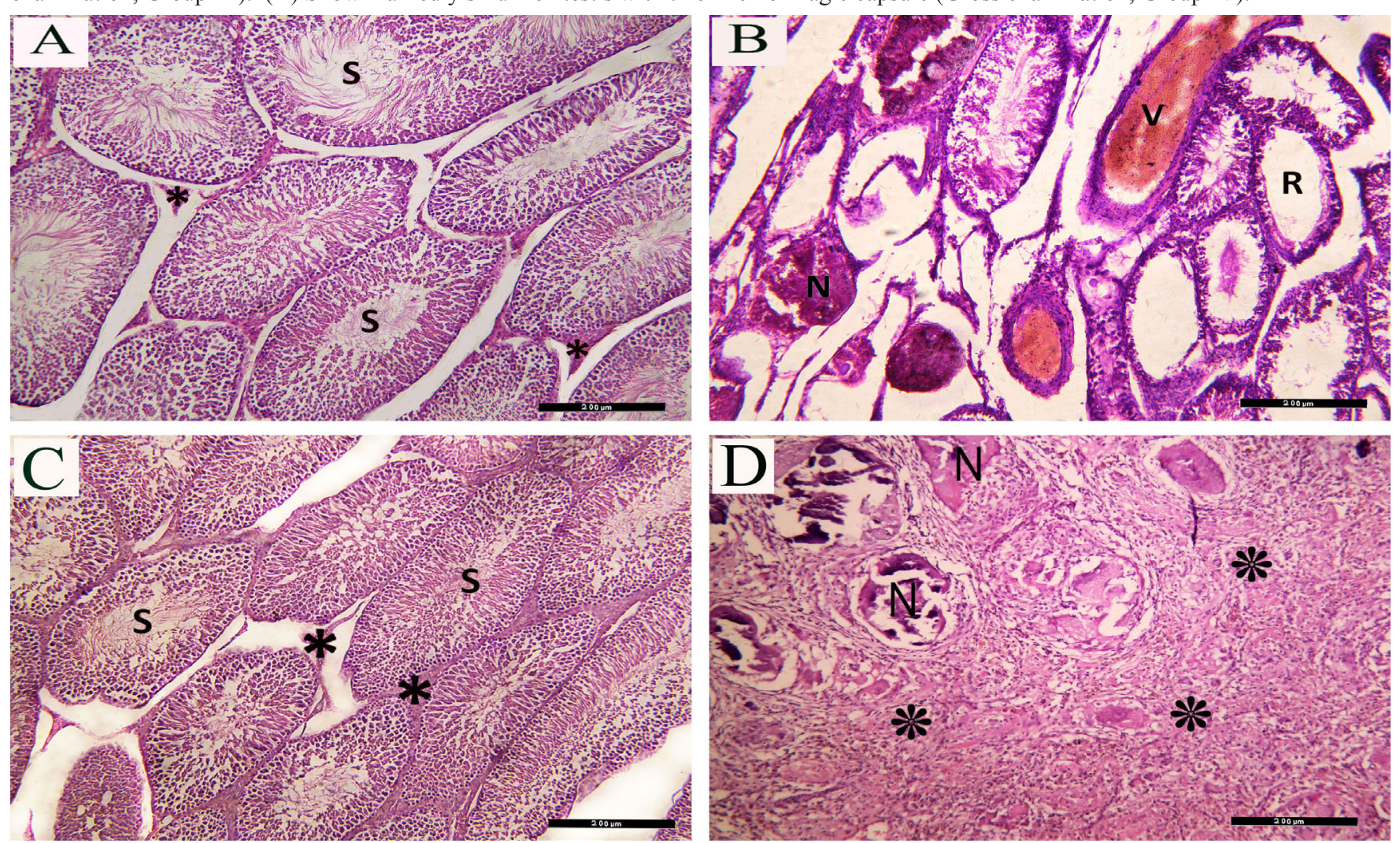

Fig. 3: (A) Show the seminiferous tubules are full of spermatogenic epithelium and sperms (S) in the lumen with minimal interstitial tissue $(*)$ in-between the tubules (Subgroup Ib, H\&E x100). (B) Show shrunken and widely separated seminiferous tubules which appear with remnants of spermatogenic cells (R). Some tubules are filled with dense hyalinosed necrotic $(\mathrm{N})$ material. Congested blood vessels (V) could be seen (Group II, H\&E x100). (C) Show seminiferous tubules are lined by spermatogenic epithelium and the sperms (S) appear filling the lumen with minimal interstitial tissue $\left(^{*}\right.$ ) (Group III, H\&E x100). (D) Show remnants of seminiferous tubules which are filled with necrotic material (N). Heavy mononuclear cells are seen infiltrating the interstitium ( $\uparrow$ (Group IV, H\&E x100). 

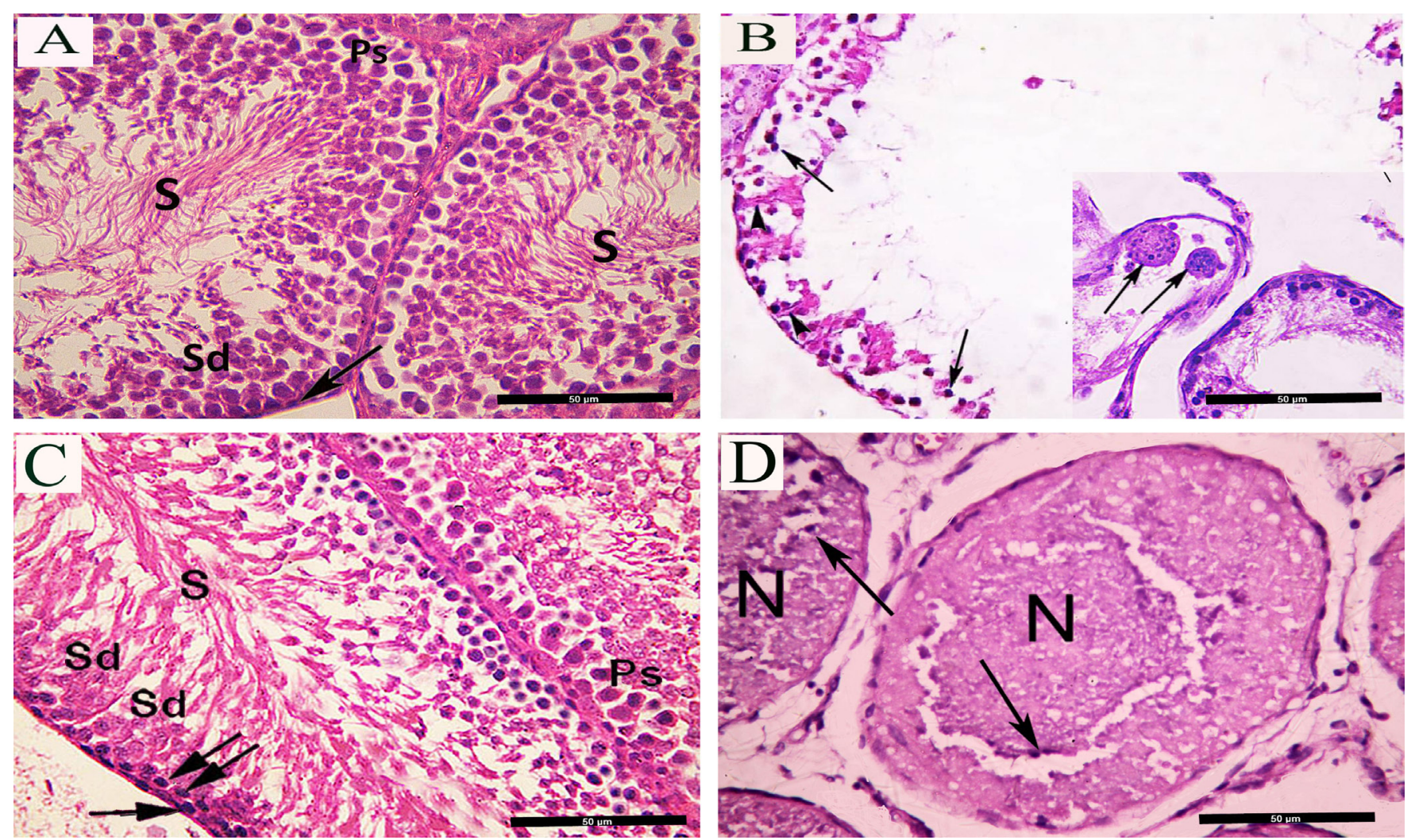

Fig. 4: (A) Show closely packed seminiferous tubules which are lined by spermatogenic epithelium in the form of spermatogonia ( $\uparrow$ ), primary spermatocytes (Ps), spermatids (Sd), and sperms (S) (Subgroup Ia, H\&E x400). (B) Show many exfoliated pyknotic nuclei ( $\uparrow$ ) of the spermatogenic cells with preservation of Sertoli cells $(\Lambda)$ only and disappearance of sperms. Large multi-nucleated giant cell $(\uparrow)$ could be seen in some tubules (inset) (Group II, H\&E x400; Inset x400). (C) Show the spermatogenic epithelium is formed of spermatogonia ( $\uparrow$ ), primary spermatocytes (Ps), early spermatids (Sd), and sperms (S) (Group III, H\&E x400). (D) Show most of the seminiferous tubules are filled with structureless necrotic tissue $(\mathrm{N})$ and sloughed pyknotic nuclei ( $\uparrow$ ) (Group IV, H\&E x400).
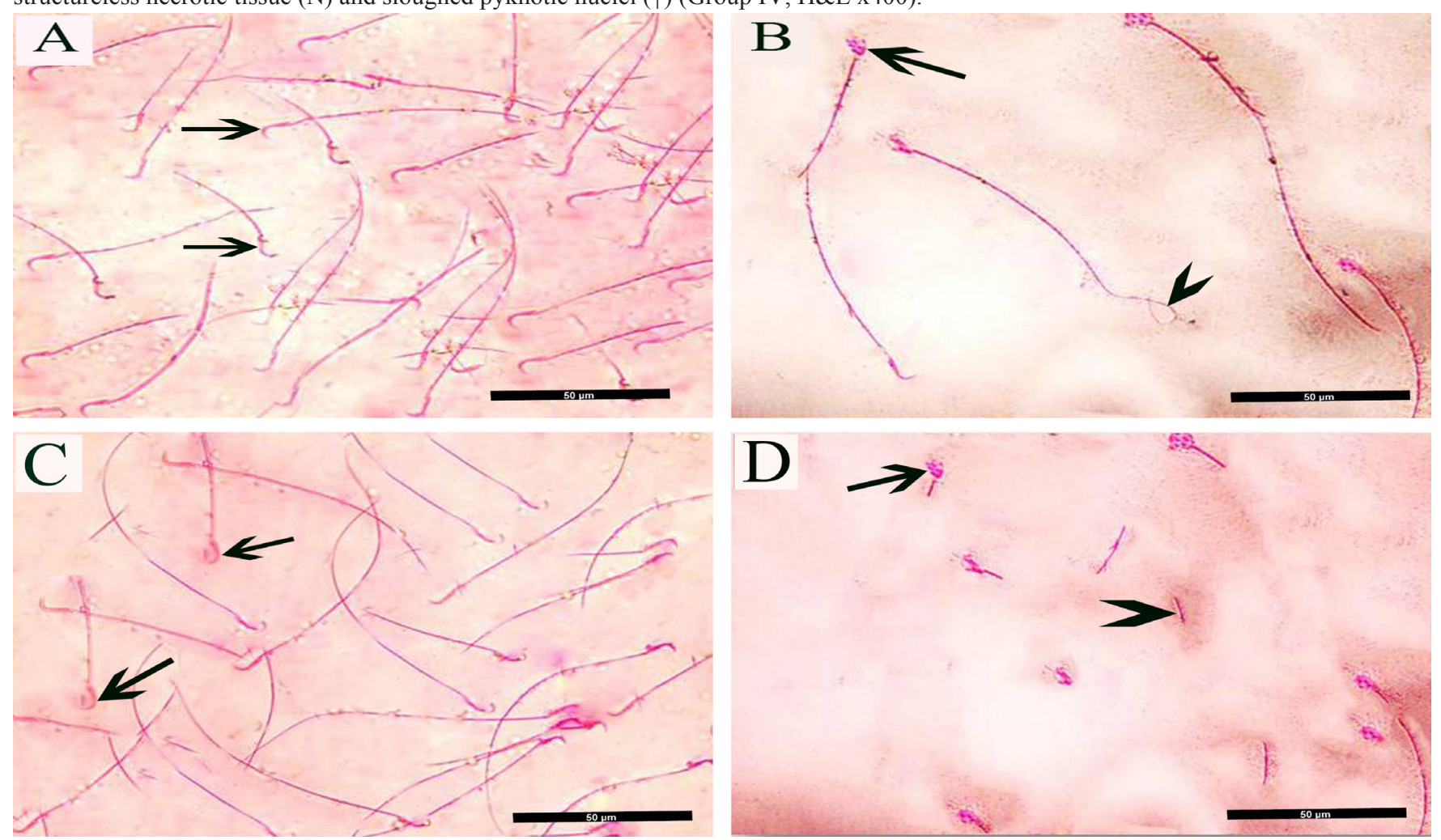

Fig. 5: (A) Show the normal sperms which reveal hook shaped heads ( $\uparrow$ ) (Subgroup Ia, sperm smear Eosin stained $x 400$ ). (B) Show the sperms appear with pyriform head $(\uparrow)$ and coiled tail ( $\Lambda$ ) (Group II, sperm smear Eosin stained x400). (C) Show normal morphology of sperms as they exhibited hook shaped heads ( $\uparrow$ ) (Group III, sperm smear Eosin stained x400). (D) Show sperms' fragments $(\Lambda)$ with detached sperms' heads ( $\uparrow$ ) (Group IV, sperm smear Eosin stained x400). 

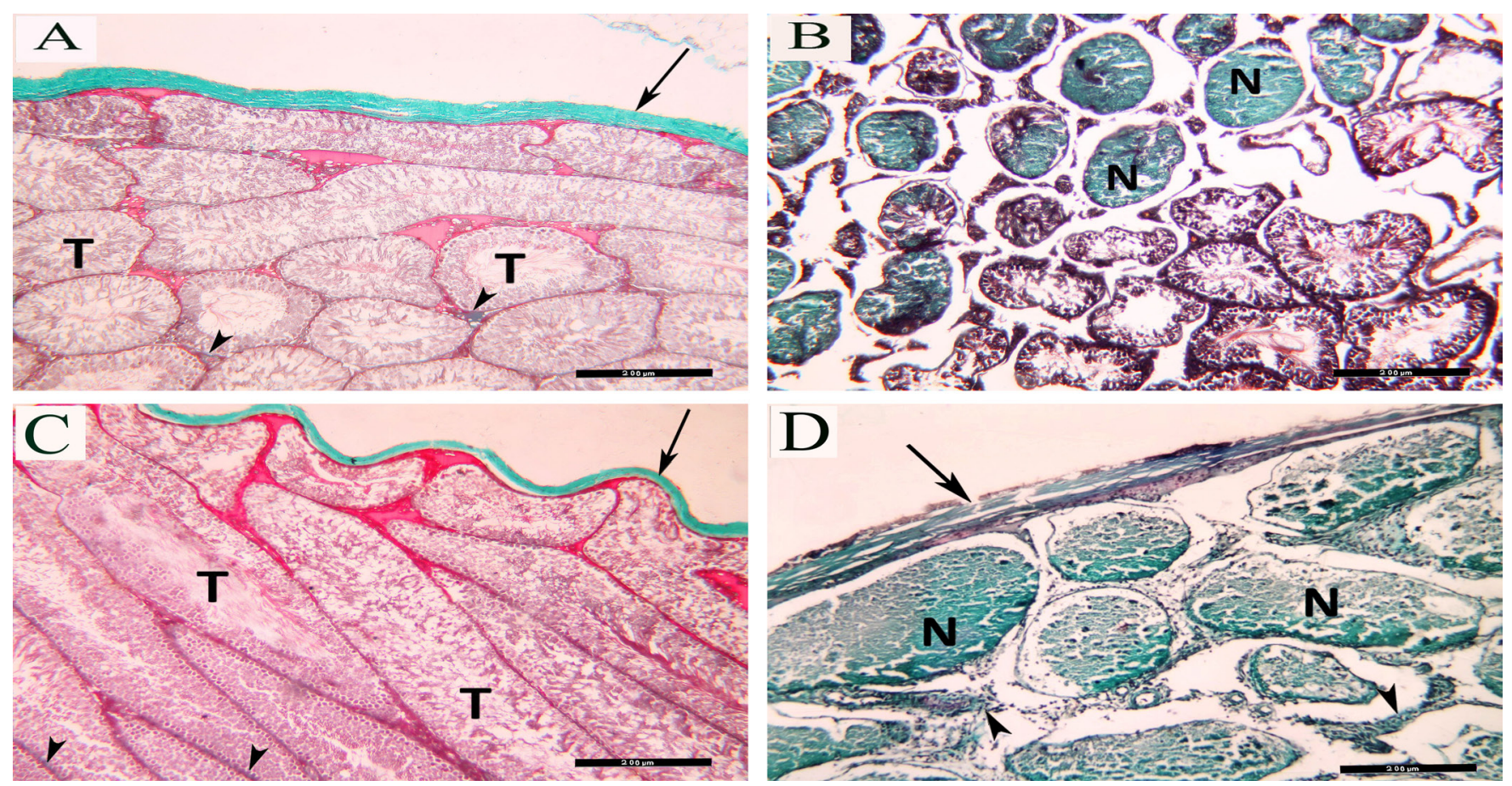

Fig. 6: (A) Show tunica albuginea $(\uparrow)$ surrounds the seminiferous tubules with minimal collagen fibers $(\Lambda)$ in between the tubules (T) (Subgroup Ia, Masson trichrome x100). (B) Show deposition of necrotic tissue (N) inside many seminiferous tubules (Group II, Masson Trichrome x100). (C) Show regular tunica albugenia ( $\uparrow$ ) with few collagen fibers ( $\Lambda$ ) in between the tubules (T) (Group III, Masson Trichrome x100). (D) Show thickened tunica albuginea with obvious splitting of its layers $(\uparrow)$ and apparent increase in the collagen fibers $(\wedge)$ deposition in between the necrotic (N) seminiferous tubules (Group IV, Masson Trichrome x100).


Fig. 7: (A) Show the seminiferous tubule are lined by spermatogenic epithelium and surrounded by a basement membrane ( $\uparrow)$ with its characteristic trilaminar structure. Primary spermatocytes (Ps) appear with large euchromatic nuclei and many mitochondria $(\Lambda)$. Sertoli cells (St) are seen in the basal compartment with their characteristic folded nuclei (Subgroup Ib, TEM x 3000). (B) Show spermatogenic cells appear distorted with many cytoplasmic vaculations $(*)$ and fragmented nuclei $(\Lambda)$. Basement membrane $(\uparrow)$ appears thickened and trapping some cellular debris $(\uparrow \uparrow)$. Sertoli cell (St) with moderately electron dense nucleus could be seen (Group II, TEM x4000). (C) Show the seminiferous tubule is lined by spermatogonium $(\mathrm{Sg})$, primary spermatocyte $(\mathrm{Ps})$, and spermatid $(\mathrm{S})$. Sertoli cells $(\mathrm{St})$ with numerous mitochondria (m) are seen resting on a regular trilaminar basement membrane ( $\uparrow$ ) (Group III, TEM x3000). (D) Show complete cellular loss of the seminiferous tubule with only cellular debris and cytoplasmic vacuolations $\left.{ }^{*}\right)$ could be seen. The basement membrane appears thickened and highly corrugated $(\uparrow)$ with increased collagen fibers deposition ( $\Lambda$ ) (Group IV, TEM x6000). 

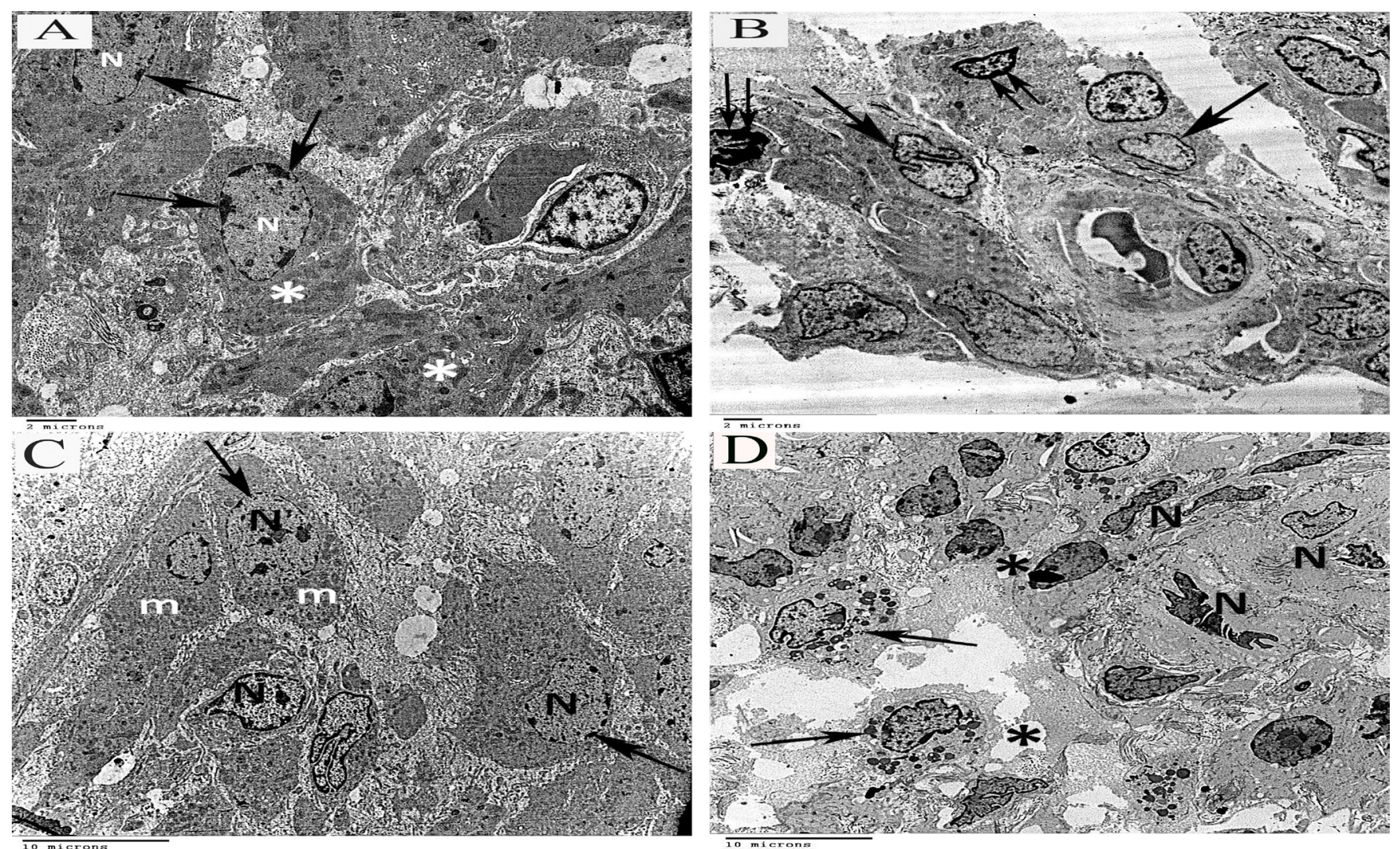

Fig. 8: (A) Show cluster of Leydig cells reveal eccentric nuclei $(\mathrm{N})$ with peripherally arranged chromatin $(\uparrow)$ and numerous mitochondria $(*)$ (Subgroup Ib, TEM x 5000). (B) Show aggregate of interstitial cells of Leydig; some of them exhibited electron dense nuclei ( $\uparrow$ ) and others have shrunken infolded nuclei ( $\uparrow$ ) (Group II, TEM x4000). (C) Show Leydig cells appear with many mitochondria (m) and eccentric nuclei with peripherally arranged chromatin (Group III, TEM x3000). (D) Show markedly distorted Leydig cells as they show irregular fragmented dark nuclei $(\mathrm{N})$. The interstitial tissue appears vaculated $(*)$ with macrophages $(\uparrow)$ inbetween (Group IV, TEM x3000). Diagram (A). Flow cytometry analysis showing (1) +ve CD90 and (2)-ve CD45 for ADMSCs after passage three (P3).

\section{DISCUSSION}

The incidence of male infertility has increased over the past decades. Although the causes of male infertility could vary, yet they all resulted in either oligospermia or azoospermia. Many hormones ${ }^{[5]}$ and drugs $^{[6]}$ were tried to correct NOA as an important cause of male infertility but with very limited benefit.

In the current work, the sexual behavior decreased in groups II and IV being severely affected in group IV with no offspring's were obtained after mating. This could be explained by the significant decrease in the testosterone level detected in these two groups as compared to the control group. Similarly, this was reported by ${ }^{[18]}$ who explained the crucial role of testosterone for sexual desire. This reduction in plasma testosterone level was also explained by a defect in the activities of testicular hydroxyl steroid dehydrogenase after $\mathrm{CaCl}_{2}$ administration which represents a key enzyme for testicular androgen synthesis ${ }^{[15]}$.

One week after $\mathrm{CaCl}_{2}$ administration in group II, there was a marked alteration in the structure of the testis which was exaggerated after 9 weeks (group IV) and this was supported by the morphometric and statistical results. This could be attributed to the time dependent effect of $\mathrm{CaCl}_{2}$ administration.
The necrotizing effect of $\mathrm{CaCl}_{2}$ could be explained by its ability to generate tissue free radicals which act as inhibitors of spermatogenesis and testicular androgenesis ${ }^{[19]}$. Reactive oxygen species also cause DNA fragmentation and protein degradation leading to cell apoptosis ${ }^{[20]}$. These findings could explain the present light and electron microscopic results of both groups II and IV which revealed degenerated spermatogenic cells with pyknotic nuclei and vacuolated cytoplasm.

On the other hand, the appearance of multinucleated giant cells in some testicular sections of group II could be attributed to incomplete cytokinesis of the germ cells. During some types of degeneration, the cytoplasmic bridges; a normal finding during germ cells division; coalesce and fuse together forming these multinucleated giant cells ${ }^{[21]}$. Furthermore, the presence of multinucleated giant cells was a suggestive sign of apoptosis ${ }^{[22]}$. In addition $^{[23]}$ stated that spermatogenic cells are very sensitive to toxic agents, therefore degenerative changes; such as formation of multinucleated giant cells; are readily apparent after exposure to such agents.

In Masson trichrome stained sections, groups II and IV of the present study showed necrotic tissues and increased collagen fibers deposition inside the 
seminiferous tubules. These results were proved by many previous studies ${ }^{[14,15]}$ which reported that many factors that released from chronic inflammatory cells could initiate the process of fibrosis. In addition, intra-tubular fibrosis could be mediated through epithelium transformation into another type of tissue e.g. connective tissue in response to sever injury and this phenomenon is called epithelial mesenchymal transformation $^{[24]}$. This transformation is mediated by inflammatory cells and fibroblasts that release inflammatory extracellular matrix signals which are known as epithelial mesenchymal transformation type $\mathrm{II}^{[25]}$.

According to the present study, Sertoli cells were the most resistant cells in groups II and IV as observed by light and electron microscopic examination. This result coincided with Sertoli cell only form of $\mathrm{NOA}^{[26]}$ as Sertoli cells act as testicular macrophages which phagocytose cytoplasmic remnants shed during spermiogenesis ${ }^{[23]}$.

Moreover, the basement membranes of the seminiferous tubules in groups II and IV appeared corrugated and trapping cellular debris between their layers. These findings are suggestive signs of necrosis as reactive oxygen species overproduction by $\mathrm{CaCl}_{2}$ is associated with lipid peroxidation, the process in which the free radicals "steel" electrons from membrane lipids, resulting in their damage, especially polyunsaturated fatty acids ${ }^{[27]}$.

Concerning Leydig cells, groups II and IV showed variable degrees of degenerative changes in the form of shrunken pyknotic nuclei with folded and thickened nuclear membrane and absence of cytoplasmic organelles. Similar findings were detected by ${ }^{[28]}$ who attributed that to increased levels of IL1 and TNFa which released from the activated macrophages.

In the recent years; in the era of stem cell applications; stem cells become a promising point of research as a possible therapeutic agent in male infertility ${ }^{[9]}$. Adipose tissue derived mesenchymal stem cells (ADMSCs) represented an attractive pool of multipotent adult stem cells because of their relative abundance and ease of isolation ${ }^{[29]}$ with considerable proliferative capacity, production of huge cellular number, and can be expanded for longer periods of time than bone marrow-derived stem cells ${ }^{[30]}$.

After administration of ADMSCs in group III, the general behavior as well as the sexual performance was comparable to that of the control group with capability of giving offspring's. These went hand in hand with the significant elevation in serum testosterone level as compared with groups II and IV with subsequent significant sperm count elevation. The structure of the testes were preserved and showed a great improvement as it nearly resembled that of the control group.

The valuable role of ADMSCs in the testicular repair after $\mathrm{CaCl}_{2}$ administration could be attributed to three main mechanisms. Firstly, ADMSCs were able to differentiate into different tissues in-vivo and in-vitro in the presence of the appropriate stem cell niche ${ }^{[31]}$. Moreover, they were able to differentiate in-vivo into male germ cells ${ }^{[32]}$.

Regarding the testicular niche, it includes many factors as Sertoli cells, the basement membrane, and many external signals. However, Sertoli cells could be considered as the most important factor as they secrete Sertoli cell derived growth factor and glial cell line neurotrophic factor for spermatogenic stem cells proliferation and differentiation ${ }^{[33]}$. The previous findings strongly supported that Sertoli cell was the main cell type that was preserved following $\mathrm{CaCl}_{2}$ administration in group II. Accordingly, it could be deduced that the transplanted ADMSCs came in contact with the niche and trans-differentiated by the secreted cytokines from the Sertoli cells.

Secondly, ADMSCs had the ability to suppress the inflammatory reaction produced by $\mathrm{CaCl}_{2}{ }^{[34]}$. Adipose tissue derived mesenchymal stem cells (ADMSCs) are characterized by being hypoimmunogenic cells as they lack MHC Class II expression but they express MHC Class I molecules ${ }^{[35]}$. Moreover, ADMSCs could stimulate the remaining spermatogenic cells to proliferate and complete their division to restore normal spermatogenesis ${ }^{[36]}$.

Furthermore, there is dispute concerning the relation between ADMSCs and natural killer (NK) cell. Previous researches stated that ADMSCs could escape NK cells, however, more recent studies reveals that NK cells could efficiently lyse MSCs. Moreover, MHC Class I; expressed on ADMSCs; acts as an inhibitory factor for NK cells, suppresses proliferation of NK cells, and decreases the secretion of IFN- $\gamma$ by activated NK cells ${ }^{[37]}$.

Finally, ADMSCs act as a stimulatory factor for the remaining resident spermatogenic stem cells in the testis. Adipose tissue derived mesenchymal stem cells (ADMSCs) also express pluripotent markers as OCT4, SOX2, Rex1, and FoxD3 that affect spermatogenesis ${ }^{[38]}$. In addition, ADMSCs could secrete high levels of vascular endothelial cell growth factor which reduce apoptosis, insulin-like growth factor-1 which believed to stimulate stem cells proliferation, and hepatocyte growth factor which represents an anti-apoptotic factor. These secreted cytokines could induce mRNA and protein expression to repair the damaged testes ${ }^{[39]}$.

All the previous findings strongly suggest the crucial role of ADMSCs in the testis repair after 
$\mathrm{CaCl}_{2}$ administration and could explain the marvelous improvement in the histological structure and morphometric parameters recorded in the testes of rats with chemically-induced castration in group III.

\section{CONCLUSION}

It is concluded that ADMSCs injection was an effective treatment for NOA. Adipose tissue derived mesenchymal stem cells (ADMSCs) can trans-differentiate into functionally active spermatogenic epithelial cells and Leydig cells and can help the spermatogonial stem cells to complete their proliferation in addition to their antiinflammatory action.

\section{RECOMMENDATIONS}

Further experimental studies are needed using different duration of treatment and doses of ADMSCs to get the maximum benefit. In addition, long-term follow up of the transplanted ADMSCs is recommended for accurate assessment of their role and fate in the castrated testes to reach solid conclusions before the future clinical applications.

\section{CONFLICT OF INTEREST}

The authors declare that no funding or grant was received for the study and they have no conflict of interest related to the study.

\section{REFERENCES}

1. Paul R, Fahd N, Yulian Z., 2012. Effects of Pharmaceutical Medications on Male Fertility. J Reprod Infertil. 13(1): 3-11.

2. Gianpiero, Palermo D, Kocent J, Monahan D, Queenie V, Zev R. Treatment of Male Infertility Methods and Protocols. Methods in Molecular Biology. 2014; 1154: 385-405.

3. Kumar R. Medical management of non-obstructive azoospermia. Clinics. 2013; 68 (S1): 75-79.

4. Deying Z, Xing L, Jinpu P, Dawei H , Tao L, Jing Z , Xuliang L, Yuanyuan Z, Guanghui W. Potential Spermatogenesis Recovery with Bone Marrow Mesenchymal Stem Cells in an Azoospermic Rat Model. Int. J. Mol. Sci. 2014; 15: 13151-13165.

5. Fraietta R, Daniel S, Sandro C. Hypogonadotropic Hypogonadism Revisited. Clinics. 2013; 68(S1): 8188.

6. Boback M, Peter N. Azoospermia due to Spermatogenic Failure. Urol Clin N Am. 2014; 41: 97-113.

7. Cihangir C, Bugra B, Gokhan D, Ahmet HH, Ayca A, Ayca IJ, Orhan U, Huseyin U, Cansu S, Erdal
K. Recovery of fertility in azoospermia rats after injection of adipose tissue-derived mesenchymal stem cells: The sperm generation. BioMed Research International. 2013; Article ID 529589: 18 pages (http://dx.doi.org/10.1155/2013/529589).

8. Bieback K, Kluter H. Mesenchymal stromal cells from umbilical cord blood. Current Stem Cell Research Therapy. 2007; 2 (4): 310-333.

9. Aranguren $\mathrm{X}$, Verfaillie $\mathrm{C}$, Luttun A. Emerging hurdles in stem cell therapy for peripheral vascular disease. Journal of molecular medicine January. 2009; 87 (1): 3-16.

10. Zuk P, Min Z, Peter A, Daniel A, Jerry I, Hiroshi M, Zeni C, John K, Prosper B, Marc H. Human Adipose Tissue Is a Source of Multipotent Stem Cells. Molecular Biology of the Cell. 2002; 3: 4279-4295.

11. Jeffrey M, Adam J, Bruce A. Adipose-Derived Stem Cells for Regenerative Medicine. American Heart Association, Circulation Research. 2007; 100: 12491260 .

12. Mcintosh K, Zvonic S, Garrett S, Mitchell J, Floyd Z, Hammill L, Kloster A, Halvorsen Y, Ting JP, Storms RW, Goh B, Kilroy G, Wu X, Gimble J. The immunogenicity of human adipose derived cells: temporal changes in vitro. Stem Cells. 2006; 24:12451253.

13. Puissant B, Barreau C, Bourin P, Clavel C, Corre $\mathrm{J}$, Bousquet C, Taureau C, Cousin B, Abbal M, Laharrague P, Penicaud L, Casteilla L, Blancher A. Immunomodulatory effect of human adipose tissuederived adult stem cells: comparison with bone marrow mesenchymal stem cells. Br J Haematol. 2005; 129: $118-129$.

14. Jana K, Samanta P, Ghosh D. Dose dependent response to an intratesticular injection of $\mathrm{c}$ alcium chloride for induction of chemosterilization in adult albino rats. Veterinary Research Communicat ions.2002; 26 (8): 651-673.

15. Jana K, Samanta P, Ghosh D. Evaluation of single intratesticular injection of calcium chloride for nonsurgical sterilization of male Black Bengal goats (Capra hircus): a dose dependent study. Anim Reprod Sci.2005; 86: 89-108.

16. Peng L, Run Z, Haitao S, Lei C, Fang L, Chen Y, Mouxuan D, Xiaodan J.PKH26 Can Transfer to Host Cells in Vitro and Vivo stem cells and development.2013; 22( 2):340-344.

17. Adekunle A, Alabi A, Olusanmi A, Hafeez B. Genotoxicity assessment of a pharmaceutical effluent using four bioassays. Genetics and Molecula r Biology. 2009; 32(2):373-381. 
18. Jana K, Samanta P. Clinical Evaluation of Non-surgical Sterilization of Male Cats with Single Intra-testicular Injection of Calcium Chloride. BMC Veterinary Research. 2011;2011:7-39.

19. Jana K, Samanta P, DK D. Nicotine diminishes testicular gametogenesis, steroidogenesis and steroidogenic acute regulatory protein expression in adult albino rats: possible influence on pituitary gonadotropins and alteration of testicular antioxidant status. Toxicol Sci.2010; 116:647-659.

20. Mishra D, Shaha C. Estrogen induced spermatogenic cell apoptosis occurs via the mitochondrial pathway. $\mathrm{J}$ Biol Chem.2005; 280:6181-6196.

21. Dianne M, Robert R, Dipak K. Non neoplastic lesion atlas, Testis, Seminiferous tubules, Giant cells. National toxicology program.2014;1-3 (http:// ntp.niehs.nih.gov/nnl/male_reproductive/testis/ setubmgcel/index.htm).

22. $\mathrm{Xu} \mathrm{C}, \mathrm{Lu} \mathrm{M}$, Feng J, Guo Q, Wang X. Germ cell apoptosis induced by Ureaplasma urealytium infection. Asian J Androl. 2001;(3):199-204.

23. Ross M, Pawlina W. A text and atlas of Histology with correlated cell and molecular biology. 7th ed. Lippincott Williams and Wilkins; 2015:790-808.

24. Raghu K, Robert A. The basics of epithelialmesenchymal transition. J. Clin. Invest.2009; 119: 1420-1428.

25. Potenta S, Zeisberg E, Kalluri R. The role of endothelial to mesenchymal transition in cancer progression. Br. J. Cancer.2008; 99: 1375-1379.

26. Je zek D. Atlas on the Human Testis: Normal Morphology and Pathology. Springer, London, UK; 2013:Chapter: 1-3 (http://www.springer.com/978-14471-2762-8).

27. NataliaA. and Gennadii P. 2012. MolecularMechanisms of Cytotoxicity and Apoptosis Induced by Inorganic Fluoride. ISRN Cell Biology; dx.doi. org/10.5402/2012/403835.

28. Trpimir G, Alexander B, Jessica C, Viviana K, Marin K, Maja M, Miro K, Celjko K, Davor J. Macrophages and Leydig Cells in Testicular Biopsies of Azoospermic Men. BioMed Research International. 2014; dx.doi. org/10.1155/2014/828697.

29. Umesh D, Michael S, Ravindra K, Sadanand F. Advances in Adipose-Derived Stem Cells Isolation, Characterization and Application in Regenerative
Tissue Engineering. Stem Cells International. 2016; dx.doi.org/10.1155/2016/3206807.

30. López M, Bollag R, Yu J, Isales C, Eroglu A. Chemically Defined and Xeno-Free Cryopreservation of Human Adipose-Derived Stem Cells. PLoS ONE. 2016;11(3): e0152161.

31. Yunfan H, Feng L. Development of Synthetic and Natural Materials for Tissue Engineering Applications Using Adipose Stem Cell. Stem Cells International. 2016; dx.doi.org/10.1155/2016/5786257.

32. Mehrabani D, Hassanshahi MA, Tamadon A, Zare S, Keshavarz S, Rahmanifar F Dianatpour M, Khodabandeh Z, Jahromi I, Tanideh N, Ramzi M, Aqababa H, Kuhi H. (): Adipose tissue-derived mesenchymal stem cells repair germinal cells of seminiferous tubules of busulfan-induced azoospermic rats. J Hum Reprod Sci.2015; 8:103-110.

33. Tadokoro $\mathrm{Y}$, Yomogida $\mathrm{K}$, Ohta H, Tohda A, Nishimune Y. Homeostatic regulation of germinal stem cell proliferation by the GDNF/FSH pathway. Mechanisms of Development.2002; 113(1): 29-39.

34. Kemp K, Gordon D, Wraith D, Mallam E, Hartfield E, Uney J, Wilkins A, Scolding N. (): Fusion between human mesenchymal stem cells and rodent cerebellar Purkinje cells. Neuropathology and Applied Neurobiology. 2011; 37 (2): 166-178.

35. Abdi R, Fiorina P, Adra C, Atkinson M, Sayegh M. Immunomodulation by mesenchymal stem cells: a potential therapeutic strategy for type 1 diabetes. Diabetes. 2008; 57:1759-1767.

36. Spees J, Olson S, Whitney M, Prockop D. Mitochondrial transfer between cells can rescue aerobic respiration. Proc Natl Acad Sci U S A.2006; 103:1283-1288.

37. Mehmet N, Ozer A, Serdar G, Mehmet A. Isolation, culturing and characterization of rat adipose tissue derived mesenchymal stem cells: a simple technique. Turk J Biol. 2012; 36: 658-664.

38. Kristensen D, Nielsen J, Skakkebaek N, Graem N, Jacobsen G, Rajpert D, Leffers H. Presumed pluripotency markers UTF-1 and REX-1 are expressed in human adult testes and germ cell neoplasms. Human Reproduction.2008; 23(4):775-782.

39. Yuji T, Akiko Y, Kenji E, Tomoko K, Rie Y, Chiaki S, Nana M, Takuya A, Ken N, Fumihito A, Naoki A, Keiich K, Osamu K. The restorative effects of adiposederived mesenchymal stem cells on damaged ovarian function. Laboratory Investigation. 2013; 93:181-193. 
الملخص العربى

\section{تأثير الخلايا الجذعية الوسيطة المشتقة من النسيج الاهني على الخصية فى نموذج للإخصاء

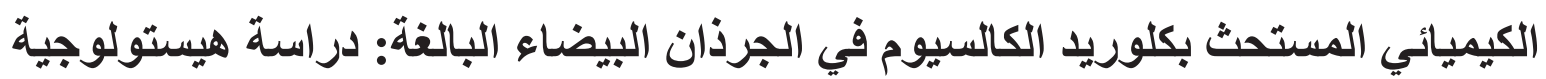

سوزى صبحى عطا الله، حنان علاء الدين صالح، سارة عبد الجواد، هند محمد

\section{قسم الهستولوجيا وبيولوجيا الخليةـ كلية الطب - جامعة عين شمس- القاهرة}

المقدمة: يسبب العقم الذكورى هץ ـ ـ ـ ٪من حالات عقم الزوجين. وبالإضافة إلى ذلك، تمثل حالات انعدام الحيو انات المنوية غير الانسدادية • ( ٪ من حالات العقم الذكورى. و لا يوجد علاج شاف أو فعال لمثل هذه الحالات. الهدف من الدراسة: تقييم الدور العلاجي للخلايا الجذعية الوسيطة المشتقة من النسيج الدهني في علاج نموذج للإخصاء الكيميائي باستخدام مادة كلوريد الكالسيوم في الجرذان البيضاء. المواد وطرق البحث: تم تقسيم عدد خمسة وأربعين من ذكور الجرذان البيضاء إلى أربع مجمو عات. المجمو عة الأولى (المجمو عة الضابطة) ، المجموعة الثانية (مجموعة كلوريد الكالسيوم) ، المجموعة الثالثة (المجموعة المعالجة بالخلايا الجذعية)، و و المجمو عة الر ابعة (مجموعة التعافى). تم تشريح الخصيتين ومعالجتها للفحص بالميكروسكوب الضوئى و الإكترونى. وقد تم إحصاء الحيو انات المنوية وقياس هرمون التستوستيرون. بالأضافة الى إجر اء مقاييس و تحاليل احصائية. النتائج: كثف الفحص الهيستولوجى للخصيتين من كلتا الهجو عتين الثانية والرابعة عن تلف شديد فى الأنابيب المنوية مع بع سقوط خلايا النسيج الطلائى المبطن للأنابيب المنوية. وقد كانت الخلايا المصاحبة اللالتهاب والخلايا الضخمة متعددة النواة و اضحة في المجموعة الثانية بينما تم الكثف عن وجود البلاعم بشكل أكثر وضوحا في المجموعة الرابعة. وتم الكثف عن ترسب ألياف الكو لاجين في النسيج الخلالى وداخل الأنابيب المنوية للخصية في المجموعة الرابعة. و قد لوحظ انخفاض ملحوظ فى عدد الحيو انات المنوية ومستوي هرمون التستوستيرون في هاتين المجمو عتين مقارنة بالمجمو عة الضابطة. أما حقن الخلايا الجذعية الوسيطة المستمدة من النسيج الدهني داخل الخصية في المجموعة الثالثة فقد أدى الى تحسن التركيب النسيجي للخصية وذللك تم تأكيده من خلال تغيير غير ملحوظ في عدد الحيو انات المنوية و مستوى هورمون التستوستيرون في الدم بالمقارنة مع بالمجمو عة الضابطة. الاستتناج: تعتبر الخلايا الجذعية الوسيطة المشتقة من النسيج الدهني بمثابة علاج فعال في حالات انعدام الحيو انات المنوية غير الانسدادية. 